\author{
Biju Michael SDB \\ Salesian Pontifical University in Rome, \\ Studium Theologicum Salesianum in Jerusalem, Israel \\ e-mail: bijumsdb@hotmail.com
}

\title{
Civilians in the Line of Fire in the Light of Catholic Social Teaching*
}

\begin{abstract}
In our world today, afflicted by wars between States, by conflict between groups within States, and by the scourge of terrorism, civilians constitute the 'vast majority of casualties in situations of armed conflict' (UN Security Council, Resolution 1894, 2009). Civilian victims of documented and un-documented armed conflicts and their destructive consequences run in the millions. An overwhelming majority of the dead, injured, disabled are civilians and damages caused by armed conflicts primarily affect the civilian infrastructure and the basic resources of subsistence of entire populations.

Civilians today are in the line of fire not only as a side effect of war. Increasingly, they are becoming the prime and intentional targets of combatants and armed elements. 'Political and military designs supersede basic respect for the dignity and rights of persons and communities' (Migliore 2009) and civilians are becoming deliberate targets and means for achieving political or military gains. They are even being used as a human shield for armed advancement.

The menace of civilian deaths in the line of fire is of utmost concern for all humanity, for all religions, and for Christianity. Among the foundational teachings on which the Catholic perspective to this important issue of placing civilians in the line of fire is based, we can identify three core beliefs: a) all human beings are equal in dignity and their life is sacred; b) the right and duty to defend the life and common good from unjust aggressors; c) the permanent validity of the moral law forbidding
\end{abstract}

\footnotetext{
* This paper is drawn from a presentation made by the author at The Institute for National Security Studies (INSS) Military and Strategic Affairs Program, Tel Aviv, Israel, and at the 'Ethics in Economic Life' Scientific Conference organized by the University of Lodz, Poland.
} 
murder even in the context of armed conflicts. After considering these the paper studies some of the ways in which the Catholic Church responds to the situation of civilians caught in the line of fire.

Keywords: conflict, civilians, Catholic church

JEL Classification: F51, Z12

\section{Introduction}

Every well-intentioned economic effort aims at improving human welfare, which includes the creation of wealth and the eradication of poverty. War, on the other hand, is a destroyer of wealth and creator of poverty for the majority of people. This article will focus on the damage caused to civilians in modern warfare and on how civilizations and religions have proposed ethical rules to guide human behaviour even in situations of war. From this case of civilians caught in the line of fire, I propose that we can infer how, even in the worst of situations, ethical guidelines should be set and respected for the good of humanity, for the creation of wealth and for the eradication of poverty. For a focused discussion on moral principles in the context of civilians in the line of fire, the Catholic Church's stand will be examined. It is hoped that this detached, yet not disconnected field will enable those involved in economic efforts to see the importance of ethics in economics.

In our world today, afflicted by wars between States, by conflict between groups within States, and by the scourge of terrorism, civilians ${ }^{1}$ constitute the "vast majority of casualties in situations of armed conflict. ${ }^{2}$ Civilian victims of documented and un-documented armed conflicts and their destructive consequences run in the millions. The UN reports a $22 \%$ rise in conflict related civilian deaths and

\footnotetext{
${ }^{1}$ A sample definition of 'civilians' used in the international society is the one given by the International Security Assistance Force (ISAF) in Afghanistan: 'International humanitarian law refers to civilians as those persons who are not combatants (members of military/paramilitary forces) or members of organized armed groups of a party to a conflict or part of a levee en mass (mass uprising). Civilians may lose their protection against attacks for such time as they take direct part in hostilities, but retain (or regain) such protection if hors de combat (i.e. wounded, sick, detained or surrendering) and thereby no longer actively participating in hostilities. Civilians will be further differentiated by their affiliation for purposes of analysis by the Civilian Casualty Mitigation Team.' Cited in United Nations Assistance Mission in Afghanistan, Protection of Civilians in Armed Conflict - Afghanistan Mid-Year Report 2012 (Kabul: United Nations Assistance Mission in Afghanistan, 2012), v.

${ }^{2}$ United Nations Security Council, Resolution 1894 (2009), preamble, http://www.unrol.org/files/Security\%20Council\%20Resolution\%201894.pdf (accessed November 23, 2013). It is more than fifteen years since the UN introduced the 'protection of civilians in armed conflict' as a thematic issue for discussion (since 1999). See the Secretary-General's report, 8 September 1999 on the Protection of Civilians in Armed Conflict (S/1999/957), http://www.un.org/ga/search/view_doc.asp?symbol=S/1999/957 (accessed November 23, 2013). A Working Group was established pursuant to resolution 1265 (1999).
} 
injuries in Afghanistan in 2014-2015. ${ }^{3}$ Because of war in Ukraine, there are 978 482 registered Internally Displaced People as of 2 February 2015.4 An overwhelming majority of the dead, injured and disabled are civilians, and damage caused by armed conflicts primarily affects the civilian infrastructure and the basic resources of the subsistence of entire populations, ${ }^{5}$ destroys the wealth created over many decades and subjects people to abject poverty.

Civilians today are in the line of fire not only as a side effect of war. Increasingly, they are becoming the prime and intentional targets of combatants and armed elements. ${ }^{6}$ 'Political and military designs supersede basic respect for the dignity and rights of persons and communities " 7 and civilians are becoming deliberate targets and means for achieving political or military gains. They are even being used as a human shield for armed advancement.

When we speak of civilians in the line of fire, it is important to be aware that armed conflicts involve huge human rights violations, particularly against women (systematic and widespread sexual violence reaching appalling levels of brutality ${ }^{8}$ ), children, people with disabilities and older persons. Along with genocide, ethnic cleansing and crimes against humanity, the issue of refugees and internally displaced persons are part of the issue of placing civilians in the line of fire. In fact, 'the overwhelming majority of internally displaced persons and other vulnerable groups in situations of armed conflict are civilians.' ${ }^{9}$ Constraints on humanitarian access and attacks against humanitarian personnel and objects are also grave concerns in this field. ${ }^{10}$

\footnotetext{
${ }^{3}$ UNAMA (United Nations Assistance Mission in Afghanistan), Strategic Communications, February 18, 2015.

${ }^{4}$ OCHA (Office for the Coordination of Humanitarian Affairs), Situation Report No. 26 as of $6^{\text {th }}$ February 2015.

${ }^{5}$ S.M. Thomasi, Statement by H.E. Archbishop Silvano M. Tomasi, Permanent Representative of the Holy See to the United Nations and Other International Organizations in Geneva at the Meeting of the High Contracting Parties to the Convention on Prohibitions or Restrictions on the Use of Certain Conventional Weapons Which May Be Deemed to Be Excessively Injurious or to Have Indiscriminate Effects $(C C W)$, Geneva, November 15, 2012, http://en.radiovaticana.va/storico/2012/11/15/statement_of_archbishop_tomasi_on_conventional_weapons_\%28full_text\%29/en1-639207 (accessed November 23, 2013). ${ }^{6}$ United Nations Security Council, Resolution 1296 (2000), preamble, http://www.undemocracy.com/SRES1296(2000).pdf (accessed November 23, 2013).

${ }^{7}$ C. Migliore, Intervention by the Holy See at the Security Council of the United Nations on the Protection of Civilians in Armed Conflicts, New York, 14 January 2009, http://www.vatican.va/roman_curia/secretariat_state/2009/documents/rc_seg-st_20090114_migliore-prot-civ_en.html (accessed November 23, 2013).

${ }^{8}$ United Nations Security Council, Resolution 1960 (2010), Preamble, http://www.unwomen.org/ / media/Headquarters/Attachments/Sections/News/In\%20Focus/16\%20Days\%20of\%20Activism/UNSC_ Res-1960.pdf (accessed November 23, 2013).

${ }^{9}$ United Nations Security Council, Resolution 1296 (2000), No. 3; United Nations Security Council, Resolution 1894 (2009), preamble. See also: The African Union Convention for the Protection and Assistance of Internally Displaced Persons in Africa (2009), http://www.africa-union.org/root/AR/index/Convention\%20on\%20IDPs \%20_Eng_\%20-\%20Final.pdf (accessed November 23, 2013).

${ }^{10}$ United Nations Security Council, Resolution 1894 (2009), preamble.
} 
In the context of the economy, another important issue is the perpetuation of poverty. Governments, international financial institutions, humanitarian organizations and civil society recognize the fact that conflicts are a major contributory factor to poverty. ${ }^{11}$ Therefore, the United Nations' Millennium Declaration, which recognized fighting poverty as an important aspect of development and peace, stressed the need for special protection of civilian victims. 'We will spare no effort to ensure that children and all civilian populations that suffer disproportionately the consequences of $(. .$.$) armed conflicts and other humanitarian emergencies are given every$ assistance and protection. ${ }^{\prime 2}$

Violence against civilians is today recognized by the UN as a serious 'threat to international peace and security. ${ }^{, 13}$ Civilian death and suffering caused by armed conflicts and, in particular, those acts of violence directed against women, children and other vulnerable groups, impede durable peace, reconciliation and development. ${ }^{14}$ Violence is often the cause of further violence because it fuels deep hatreds, creates situations of injustice and tramples upon people's dignity and rights. Violence is a defeat for humanity. ${ }^{15}$

Recognizing the problem of increasing civilian deaths in the line of fire, Pope John Paul II on January 1, 2000 stated in his message for World Day of Peace: 'All too many and horrifying are the macabre scenarios in which innocent children, women, and unarmed older people have become intentional targets in the bloody conflicts of our time; too many, in fact, for us not to feel that the moment has come to change direction, decisively and with a great sense of responsibility. ${ }^{16}$ In the context of the Ukrainian situation, Pope Francis called for prayers, especially for the civilians affected by the conflict.

The menace of civilian deaths and the destruction of wealth are of the utmost concern for all humanity, for all religions, and for Christianity. Guided by human reason and the light of revelation, the Catholic Church welcomes the efforts of the UN and all parties engaged in the humanitarian dialogue aimed at the protection of civilians caught in the line of fire. The Church stresses the need to place at the centre of every response the principles of human brotherhood, solidarity and the inherent dignity of all human beings from which follow human rights.

Gaudium et spes, the Pastoral Constitution of the Church in the Modern World as formulated by the Second Vatican Council, states in this regard: 'A firm determination to respect other men and peoples and their dignity, as well as the studied

\footnotetext{
${ }^{11}$ Holy See, Intervention by the Holy See at the Meeting of the Group of Governmental Experts, Geneva, 15-26 July 2002, http://www.vatican.va/roman_curia/secretariat_state/documents/rc_seg-st_doc_200 20723_martin-geneve_en.html (accessed November 23, 2013).

${ }^{12}$ United Nations, United Nations Millennium Declaration, adopted by the General Assembly on 8 September 2000, No. 26, http://www.un.org/millennium/declaration/ares552e.htm (accessed November 23, 2013).

${ }^{13}$ United Nations Security Council, Resolution 1296 (2000), No. 5.

${ }^{14}$ United Nations Security Council, Resolution 1296 (2000), preamble.

${ }^{15}$ John Paul II, Peace on Earth to Those Whom God Loves, Message for the Celebration of the World Day of Peace, 1 January 2000, No. 3, http://www.vatican.va/holy_father/john_paul_ii/messages/peace/documents/hf_jp-ii_mes_08121999_xxxiii-world-day-for-peace_en.html (accessed November 23, 2013).

${ }^{16}$ John Paul II, Peace on Earth..., No. 7.
} 
practice of brotherhood are absolutely necessary for the establishment of peace.' ${ }^{17}$ Pope John Paul II reiterates, 'Only in peace and through peace can respect for human dignity and its inalienable rights be guaranteed.' 18

Among the foundational teachings on which the Catholic perspective to this important issue of placing civilians in the line of fire is based, we can identify three core beliefs: (1) all human beings are equal in dignity and their life is sacred; (2) the right and duty to defend the life and common good from unjust aggressors; (3) the permanent validity of the moral law forbidding murder even in the context of armed conflicts. After considering these beliefs, the article will study some of the ways in which the Catholic Church responds to the situation of civilians caught in the line of fire.

\subsection{All human beings are equal in dignity and their life is sacred}

The Universal Declaration of Human Rights states: 'All human beings are born free and equal in dignity and rights. They are endowed with reason and conscience and should act towards one another in a spirit of brotherhood. ${ }^{19}$ The Church sees this brotherhood and equal dignity of all as stemming from the creation of man by God as narrated in the Sacred Scripture: 'God created man in the image of himself, in the image of God he created him, male and female he created them' (Gen 1:27). The psalmist states: 'Yet you have made him little less than a god, you have crowned him with glory and beauty, made him lord of the works of your hands, put all things under his feet' (Ps 8:5-6). This high dignity is further accented because of the incarnation of Christ and the redemption wrought by the blood of Christ. ${ }^{20}$

The Catechism of the Catholic Church therefore crystallizes the teaching in CCC 2258. 'Human life is sacred because from its beginning it involves the creative action of God and it remains forever in a special relationship with the Creator, who is its sole end. God alone is the Lord of life from its beginning until its end: no one can under any circumstance claim for himself the right directly to destroy an innocent human being. ${ }^{21}$ In the Book of Genesis, God asserts: 'Of man as regards his fellow man, I shall demand account for human life' (Gen 9:5). 'You shall not kill' (Ex 20:13); he instructs in the Ten Commandments. In the book of Exodus, God commands man not to cause the death of the innocent or upright (Cf. Ex 23:7). Jesus in his Sermon on the Mount affirmed the commandment 'Do not Kill' as found in

\footnotetext{
${ }^{17}$ Vatican II, Gaudium et Spes Pastoral Constitution on the Church in the Modern World (December 7, 1965), "Acta Apostolicae Sedis" (hereinafter: AAS) 58 (1966), No. 78. All the English quotations of the Church documents are taken from the official translation available at www.vatican.va.

${ }^{18}$ John Paul II, Peace on Earth..., No. 3.

${ }^{19}$ United Nations, The Universal Declaration of Human Rights, Art. 1; http://www.un.org/en/documents/udhr/ (accessed November 23, 2013).

${ }^{20}$ John XXIII, Pacem in Terris Encyclical Letter (April 11, 1963): AAS 55 (1963), No. 10.

${ }^{21}$ The Catechism of the Catholic Church: with Modifications from the Editio Typica (New York: Doubleday, 1995). Italics added. Henceforth referred to in the text as well as in the footnotes as CCC; Cf. Congregation for the Doctrine of the Faith, Donum Vitae On Respect for Human Life in Its Origin and on the Dignity of Procreation (February 22, 1987): AAS 80 (1988), Introduction.
} 
the Decalogue (Cf. Ex 20:13; Deut 5:17) and denounced even murderous anger and hatred as immoral (Cf. Mt 5:21-22; Cf. CCC 2302). Jesus preached: 'You have heard how it was said to our ancestors, You shall not kill; and if anyone does kill he must answer for it before the court. But I say this to you, anyone who is angry with a brother will answer for it before the court...' (Mt 5:21-22).

In the story of Abel's murder by Cain, the Bible recounts the role of anger that leads to murder and the wickedness of fratricide: 'What have you done? Yahweh asked. Listen! Your brother's blood is crying out to me from the ground' (Gen 4:10; Cf. CCC. 2259). God alone being the Lord of life, man will be asked to account for his own life and that of his brother who are both created in the image of God. 'And I shall demand account of your life-blood, too. ... Of man as regards his fellowman, I shall demand account for human life' (Gen 9:5-6).

The Church understands the sacredness of human life to mean the prohibition of direct murder, 'doing anything with the intention of indirectly bringing about a person's death' (CCC2269), refusing assistance to persons in danger, terrorism, kidnapping and hostage taking (CCC 2297) and even anger that reaches the point of a 'deliberate desire to kill or seriously wound a neighbor.' (CCC2302). Jesus advised, 'But I say this to you, love your enemies and pray for those who persecute you; so that you may be children of your Father in heaven, for he causes his sun to rise on the bad as well as the good, and sends down rain to fall on the upright and the wicked alike' (Mt 5:44-45).

While we acknowledge God alone as the Lord of life and recognize our duty to defend and promote the gift of life granted to us, the story of Cain and Abel reminds us of the sinful nature of man which perpetuates strife and fratricide. While all peoples look with hope to the day when 'they shall turn their swords into ploughshares, and their spears into sickles, when nation shall not lift up sword against nation, nor learn war any more' (Cf. Isaiah 2:4), we are aware that man's sinful nature keeps the threat of war ever present. ${ }^{22}$ This brings us to the second conviction, namely the legitimate defence of the innocent.

\subsection{The right and duty to defend life and common good from unjust aggressors}

The Church recognizes the legitimate right and duty of States (and all responsible people) to defend its citizens from unjust aggression. Vatican II, while in very clear terms condemning every act of war aimed at the indiscriminate destruction of entire populations, cities or extensive areas as a crime against God and man himself ${ }^{23}$, recognized the right to armed defence: 'As long as the danger of war remains and there is no competent and sufficiently powerful authority at the international level, governments cannot be denied the right to legitimate defense once every means of peaceful settlement has been exhausted.' 24 This right can become a serious duty for those who are responsible for the lives of others, for the common good of the family or of the civil community. The Catechism of the Catholic Church states, 'Legitimate

\footnotetext{
${ }^{22}$ Vatican II, Gaudium et Spes, No. 78.

${ }^{23}$ Ibidem, No. 80.

${ }^{24}$ Ibidem, No. 79. Cf. CCC 2308.
} 
defense can be not only a right but a grave duty for one who is responsible for the lives of others. The defense of the common good requires that an unjust aggressor be rendered unable to cause harm. For this reason, those who legitimately hold authority also have the right to use arms to repel aggressors against the civil community entrusted to their responsibility' (CCC 2265). The possession or the transfer of arms is justified only by this right. ${ }^{25}$

This duty and right to defend its citizens gives public authorities 'the right and duty to impose on citizens the obligations necessary for national defense' (CCC 2310).

Soldiers and all who devote themselves to the military service of their country are 'agents of security and freedom of peoples' and 'as long as they fulfil this role properly,' they genuinely contribute to the establishment of peace. ${ }^{26}$

Every right to defend comes with duties to choose the means wisely. As Gandhi said, 'The Ganges of rights flows from the Himalayas of duties.' Since the gravity of entering into armed conflict or war is great, traditional wisdom has distilled strict conditions for legitimacy. The following conditions considered by the prudential judgment of those who are responsible for the common good must apply at one and the same time: a) the damage inflicted by the aggressor on the nation or community of nations must be lasting, grave, and certain; b) all other means of putting an end to it must have been shown to be impractical or ineffective; c) there must be a serious prospects of success; and d) the use of arms must not produce evils and disorders graver than the evil to be eliminated (Cf. CCC 2309). However, given the pervasive power of destruction in modern warfare, there is hardly any chance to justify a war. Violence and war are the language of death; they are never the way to peace. ${ }^{27}$ Wars only cause further wars by fuelling deep hatreds and situations of injustice causing horrendous human rights violations and the violation of human dignity; 'war is a defeat for humanity' 28 and so all Christians are called to prayer and action to free the world from 'the ancient bondage of war.' 29

The legitimacy of the defence of persons and societies is not an exception to the prohibition against the murder of the innocent that constitutes intentional killing (Cf. CCC 2263). ${ }^{30}$ Christ gave the fullest example of non-violence. Christ did not defend himself and told Peter to leave his sword in its sheath (Cf. Mt 26:52; CCC 2262). This brings us to the third core belief that influences the Catholic teaching on civilians in the line of fire.

\footnotetext{
${ }^{25}$ Pontifical Council for Justice and Peace, The International Arms Trade, An ethical reflection (Vatican City: Libreria Editrice Vaticana, 1994), 12-13; Cf. John XXIII, Pacem in Terris, Part III; Cf. CCC 2304.

${ }^{26}$ Vatican II, Gaudium et Spes, No. 79.

${ }^{27}$ Francis, War is a defeat for humankind, Pope Francis' homily during peace vigil, September 7, 2013, http://www.romereports.com/palio/pope-francis-homily-during-peace-vigil-war-is-a-defeat-for-humankind-english-10953.html\#.UpDT4XmIodU (accessed November 23, 2013).

${ }^{28}$ John Paul II, Peace on Earth..., No. 3.

${ }^{29}$ Vatican II, Gaudium et Spes, 79; Cf. CCC 2307.

30 'The act of self-defense can have a double effect|: the preservation of one's own life; and the killing of the aggressor ... The one is intended, the other is not.' Thomas Aquinas, Summa Theologiae, II-II, 64.7; Cf. CCC 2263.
} 


\subsection{The permanent validity of the moral law forbidding murder exists even in the context of armed conflicts}

The moral law forbidding the "deliberate murder of an innocent person is gravely contrary to the dignity of the human being, to the golden rule, and to the holiness of the Creator. The law forbidding it is universally valid: it obliges each and every one, always and everywhere" (CCC 2261). Both, human reason and the Church, assert the permanent value of the moral law during armed conflict (Cf. CCC 2312). Therefore, 'the mere fact that war has regrettably broken out does not mean that everything becomes licit between the warring parties. ${ }^{31}$ When, despite every effort to prevent it, armed conflict breaks out, 'at least the essential principles of humanity and the basic values of all civil coexistence must be safeguarded; norms of conduct must be established that limit the damage as far as possible and help to alleviate the suffering of civilians and of all the victims of conflicts' ${ }^{32}$ The Catechism stipulates that non-combatants, wounded soldiers, and prisoners must be respected and treated humanely, and it condemns as grave crimes the extermination of a people, nation, or ethnic minorities (Cf. CCC 2313; Cf. GS 79). The indiscriminate destruction of whole cities or vast areas with their inhabitants is also considered a grave sin (Cf. GS 80; CCC 2314).

History bears witness to the power of human reason which recognizes that in military conflicts the right of parties to choose the means and methods of warfare is not unlimited. Not everything is acceptable. ${ }^{33}$ The human conscience is a witness to the permanent binding force of universal natural law and its all-embracing principles which forbid the direct destruction of human life. ${ }^{34}$ Civilian casualties cannot be explained away as simple collateral damage.

This recognition in the international community 'that there exist inalienable human rights connected to our common human nature ${ }^{35}$ gave rise, in the $20^{\text {th }}$ century, to the Geneva Conventions (1949) and the various international humanitarian laws which represent the minimum standards that should be maintained when violence has erupted.

\footnotetext{
${ }^{31}$ Vatican II, Gaudium et Spes, 79.

${ }^{32}$ Benedict XVI, The Human Person the Heart of Peace: Message of His Holiness Pope Benedict XVI for the Celebration of the World Day of Peace, January 1, 2007, No. 14, http://www.vatican.va/holy_father/benedict_xvi/messages/peace/documents/hf_ben-xvi_mes_20061208_xl-world-day-peace_en.html (accessed November 23, 2013).

${ }^{33}$ S.M. Thomasi, Statement by H.E. Archbishop Silvano M. Tomasi Permanent Representative of the Holy See to the United Nations and Other International Organizations in Geneva at the Meeting of the High Contracting Parties to the Convention on Prohibitions or Restrictions on the Use of Certain Conventional Weapons Which May Be Deemed to Be Excessively Injurious or to Have Indiscriminate Effects (CCW).

${ }^{34}$ Vatican II, Gaudium et Spes, 79.

${ }^{35}$ Benedict XVI, The Human Person the Heart of Peace, No. 14.
} 


\section{The Right of Civilians to Safety}

We have so far discussed the three main convictions that form the foundation of the Church's understanding of the situation of civilians in the line of fire. The Church is convinced of the brotherhood of all human beings; in the equal and exalted dignity of each and every human being, of the legitimate right to defend oneself and those in one's care; and of the rightful and moral limitations in the choice of means while defending oneself or one's wards.

The obvious conclusion that follows from the above convictions is that, 'in no kind of conflict is it permissible to ignore the right of civilians to safety. ${ }^{36}$ Every direct attack on unarmed civilians is total disrespect for the sacredness of life. 'Noncombatants, wounded soldiers and prisoners must be respected and treated humanely' (CCC 2313). Peace will exist between human beings 'only to the extent that humanity as a whole rediscovers its fundamental calling to be one family, a family in which the dignity and rights of individuals - whatever their status, race or religion - are accepted as prior and superior to any kind of difference or distinction. ${ }^{37}$ Every offence against human rights is an offense against the conscience of humanity itself. Human rights are universal and indivisible and therefore they have no borders. Hence, crimes against humanity cannot be considered an internal affair of a nation. Protection of civilians from the violation of their fundamental rights is therefore the responsibility of each human being as a member of the human family and it is a special responsibility of the international community. ${ }^{38}$

Now we can proceed to look at some of the ways in which the Church contributes to the defence of civilians suffering the effects of armed conflicts.

\section{The Church's response to the situation of civilians in the line of fire}

The joys and the hopes, the suffering and the anxieties of people, especially those who are poor and afflicted, are the joys and the hopes, the suffering and the anxieties of the followers of Christ. ${ }^{39}$ Mindful of the Lord's saying: 'by this will all men know that you are my disciples, if you have love for one another' (Jn 13:35), Christians continue to serve the men of the modern world with ever greater generosity. ${ }^{40}$ The Church is called to cooperate with every agent working for the common good of humanity ${ }^{41}$ and so she is a signatory to the Geneva Convention (signed on February $22,1951)$ which the UN considers to constitute the basis for the legal framework

\footnotetext{
${ }^{36}$ John Paul II, Peace on Earth..., No. 12.

${ }^{37}$ Ibidem, No. 5.

${ }^{38}$ Ibidem.

${ }^{39}$ Vatican II, Gaudium et Spes, 1.

${ }^{40}$ Ibidem, 93.

${ }^{41}$ Ibidem, 10, 77.
} 
for the protection of civilians in armed conflict. ${ }^{42}$ The Church acknowledges that the highest responsibility to respect and ensure the human rights of their citizens and all those living within their territory lies with the States and that the parties to armed conflict bear the primary responsibility to take all feasible steps to ensure the protection of civilians. ${ }^{43}$ The Church, while highlighting humanitarian access, the special protection of women and children and disarmament, ${ }^{44}$ agrees with and supports efforts to combat the core challenges to the effective protection of civilians as identified by the Secretary General of the UN in May 2009: (1) enhancing compliance with international law; (2) enhancing compliance by non-State armed groups with their obligations under international law; (3) enhancing protection through more effective and better resourced United Nations peacekeeping and other relevant missions; (4) enhancing humanitarian access; and (5) enhancing accountability for violations. ${ }^{45}$

\section{Support and promotion of international humanitarian law}

Recognizing the role of the international community in the defence of human rights, the Church gives her full support to international humanitarian laws. The Second Vatican Council, with the supreme authority of the Church called on all people, especially government officials and experts, to honour these agreements and improve upon them. ${ }^{46}$ Pope John Paul II taught that the 'observance or non-observance of humanitarian laws is a real test for the ethical foundation and for the very reason for the existence of the international community.' 47

The Delegation of the Holy See to the UN constantly calls on national authorities and groups in armed conflict 'to respect the rules of international humanitarian law, in particular the applicable Geneva Conventions and its optional protocols.' 48 Pope Benedict XVI asserted this even further:

As a means of limiting the devastating consequences of war as much as possible, especially for civilians, the international community has created an international humanitarian law. In a variety of situations and in different settings, the Holy See has expressed its support for this humanitarian law, and has called for it to be respected and promptly implemented, out of the conviction that the truth of peace

\footnotetext{
${ }^{42}$ United Nations Security Council, Resolution 1894 (2009), preamble.

${ }^{43}$ Ibidem.

${ }^{44}$ C. Migliore, op. cit.

${ }^{45}$ United Nations Security Council, Resolution 1894 (2009), preamble.

${ }^{46}$ Vatican II, Gaudium et Spes, 79.

${ }^{47}$ John Paul II, Address to the members of the International Institute of Humanitarian Law, May 18, 1982, cited in: S.M. Tomasi, Intervention by the Holy See at the $28^{\text {th }}$ International Conference of the Red Cross and the Red Crescent, Geneva, 11 December 2003, http://www.vatican.va/roman_curia/secretariat_state/2003/documents/rc_seg-st_20031209_red-cross_en.html (accessed November 23, 2013).

${ }^{48}$ S.M. Tomasi, Intervention by the Holy See at the Humanitarian Affairs Segment of the UN Economic and Social Council, Geneva, 20 July 2009, http://www.vatican.va/roman_curia/secretariat_state /2009/documents/rc_seg-st_20090720_tomasi-aff-uman_en.html (accessed November 23, 2013).
} 
exists even in the midst of war. International humanitarian law ought to be considered as one of the finest and most effective expressions of the intrinsic demands of the truth of peace. Precisely for this reason, respect for that law must be considered binding on all peoples. Its value must be appreciated and its correct application ensured; it must also be brought up to date by precise norms applicable to the changing scenarios of today's armed conflicts and the use of ever newer and more sophisticated weapons. ${ }^{49}$

Pope John Paul II taught that the armed measures undertaken to disarm unjust aggressors 'must be carried out in full respect for international law, guaranteed by an authority that is internationally recognized. ${ }^{, 50}$ It is also true that there is need for constant renewal of international law and international institutions. The renewal should have as its guiding principle the primacy of the good of humanity and of the human person over every other consideration. International institutions like the UN should become more credible by offering member States equal opportunity in decision making processes and by eliminating privileges and discriminations. The paradox of modern warfare in which armies enjoy maximum security while civilian populations are exposed to frightening situations of danger cries out for such renewal. ${ }^{51}$

Pope Benedict XVI expressed the Church's gratitude to the international community for the leadership it gives in promoting humanitarian laws. 'Here I wish to express gratitude to the international organizations and to all those who are daily engaged in the application of international humanitarian law. Nor can I fail to mention the many soldiers engaged in the delicate work of resolving conflicts and restoring the necessary conditions for peace. ${ }^{52}$

The vast majority of nations have signed the Geneva Conventions and its optional protocols. Yet, the current situation of 'civilians in the line of fire' shows that there is much to be achieved in the implementation of these humanitarian laws. Leaders - especially political leaders - have to translate their good will into action by choosing only legitimate means in defending their citizens or in pursuing the right to self-determination. ${ }^{53}$ For leaders and peoples to respect international humanitarian law, a paradigm shift in thinking is required. The good of humanity as a whole must prevail over the well-being of any one political, racial or cultural community. As John Paul II noted,

The pursuit of the common good of a single political community cannot be in conflict with the common good of humanity, expressed in the recognition of and respect for human rights sanctioned by the Universal Declaration of Human Rights of 1948. It is necessary, then, to abandon ideas and practices - often determined

\footnotetext{
${ }^{49}$ Benedict XVI, In Truth, Peace, Message of His Holiness Pope Benedict XVI for the Celebration of the World Day of Peace, 1 January 2006, No. 7, (italics added), http://www.vatican.va/holy_father/benedict_ xvi/messages/peace/documents/hf_ben-xvi_mes_20051213_xxxix-world-day-peace_en.html (accessed November 23, 2013).

${ }^{50}$ John Paul II, Peace on Earth..., No. 11.

${ }^{51}$ Ibidem, Nos. 11-12.

${ }^{52}$ Benedict XVI, In Truth, Peace..., No. 8.

${ }^{53}$ C. Migliore, op. cit.
} 
by powerful economic interests - which subordinate every other value to the absolute claims of the nation and the State. In this new perspective, the political, cultural and institutional divisions and distinctions by which humanity is ordered and organized are legitimate in so far as they are compatible with membership in the one human family, and with the ethical and legal requirements which stem from this. ${ }^{54}$

Genuine patriotism cannot be the fruit of jealously, competition, suspicion, desire for power or hatred. It should rather be based on genuine love of country, on a common desire for good, on fraternal trust, harmonious co-operation, respect and protection for all human rights including those of the weak and the small. ${ }^{55}$

Recognition of our being members of one and the same family is essential for this to happen. Every extreme exaltation of differences clashes with this fundamental truth. As Pope Benedict XVI pointed out, 'we need to regain an awareness that we share a common destiny which is ultimately transcendent, so as to maximize our historical and cultural differences, not in opposition to, but in cooperation with, people belonging to other cultures. ${ }^{56}$ Leaders must deliberate together in mutual trust and sincerity and fulfil all obligations assumed. ${ }^{57}$ The Second Vatican Council recognized the pressures exerted by public opinion on leaders and governments. In situations where long standing hostilities divide people and ferment distrust, governments might find it difficult to promote universal good, for they will find them opposed to the people. This requires education of public opinion and education to peace. ${ }^{58}$

Ruling authority exists for the sake of leading people on the path of moral order. ${ }^{59}$ God Himself warns rulers: 'Hear this, you who govern great populations, taking pride in your hosts of subject nations! For sovereignty is given to you by the Lord and power by the Most High, who will himself probe your acts and scrutinize your intentions. If therefore, as servants of his kingdom, you have not ruled justly nor observed the law, nor followed the will of God, he will fall on you swiftly and terribly' (Wis 6:2-5).

Leaders are called not only to care for the material welfare of their groups. They have a greater calling. Pope John XXIII closed his Encyclical Letter Pacem in Terries with this prayer: 'May He illumine with His light the minds of rulers, so that, besides caring for the proper material welfare of their peoples, they may also guarantee them the fairest gift of peace. ${ }^{60}$ Since States have the duty not only to

\footnotetext{
${ }^{54}$ John Paul II, Peace on Earth..., No. 6.

${ }^{55}$ Pius XI, Address to the Roman Curia, (December 24, 1930): AAS 22 (1930), 535-536; Cf. John Paul II, Message of His Holiness John Paul II on the Fiftieth Anniversary of the End of the Second World War in Europe, 8 May 1995, No. 7, http://www.vatican.va/holy_father/john_paul_ii/speeches/1995/may/documents/hf_jp-ii_mes_08051995_50th-end-war-europe_en.html (accessed November 23, 2013).

${ }^{56}$ Benedict XVI, In Truth, Peace, No. 6.

${ }^{57}$ John XXIII, Pacem in Terris, No. 118.

${ }^{58}$ Vatican II, Gaudium et Spes, No. 82.

${ }^{59}$ John XXIII, Pacem in Terris, No. 83

${ }^{60}$ Ibidem, No. 171.
} 
provide for their own defence they also have the serious obligation to establish conditions of peace, not only on their own territory but throughout the world. ${ }^{61}$ The Church therefore encourages its members (leaders and citizens of States) to dedicate themselves to the cause of peace in order to build a genuinely human world. The Gospel declares artisans of peace to be blessed 'because they will be called the sons of God' (Mt 5:9). ${ }^{62}$

This takes us to the second and most comprehensive response required for defending 'civilians in the line of fire'.

\section{Building a culture of peace}

Peace and not war should guide the destiny of the peoples and of all humanity. ${ }^{63}$ The cultivation of the common good of humanity requires constant effort on the part of individuals and governments to build peace. ${ }^{64}$ Peace is not merely the absence of war. It is an enterprise of justice and the fruit of love which goes beyond what justice can provide. ${ }^{65}$

Respect for and development of human life require peace. Peace is not merely the absence of war, and it is not limited to maintaining a balance of powers between adversaries. Peace cannot be attained on earth without safeguarding the goods of persons, free communication among men, respect for the dignity of persons and peoples, and the assiduous practice of fraternity. Peace is 'the tranquillity of order.' Peace is the work of justice and the effect of charity. (CCC 2304)

Peace cannot be built by force. 'Peace must be born of mutual trust between nations and not be imposed on them through fear. ${ }^{, 66}$ A paradigm shift is needed in the way the world today thinks about establishing peace through pre-emptive stockpiling of arms. True and lasting peace cannot consist in the possession of an equal supply of lethal weapons. It can be achieved only through an increase of mutual trust. ${ }^{67}$ Relationships between individuals and nations must not be regulated by armed force, but by truth, justice and sincere co-operation. ${ }^{68}$ Living by the universal moral order enshrined in human hearts (Rom 2:15) is an essential prerequisite for peace ${ }^{69}$ Recognition of God as our Father and of our membership in the family of

\footnotetext{
${ }^{61}$ Pontifical Council for Justice and Peace, The International Arms Trade: An ethical reflection, 12-13; Cf. John XXIII, Pacem in Terris, Part III; Cf. CCC 2304.

${ }^{62}$ Vatican II, Gaudium et Spes, No. 77.

${ }^{63}$ Paul VI, Address to the General Assembly of the United Nations, October 4, 1965, AAS 57 (1965), No. 5.

${ }^{64}$ Vatican II, Gaudium et Spes, No. 78.

${ }^{65}$ Ibidem.

${ }^{66}$ Ibidem, No. 81.

${ }^{67}$ John XXIII, Pacem in Terris, No. 113.

${ }^{68}$ Ibidem, No. 114; Cf. John Paul II, Peace on Earth..., No. 12.

${ }^{69}$ Benedict XVI, In Truth, Peace, No. 4; Cf. John XXIII, Pacem in Terris, No. 1.
} 
God will lead us to work for the integral development of all human beings and to protect the fundamental rights of all. The truth about God and the truth about man will create a sensitivity to justice and openness to love and solidarity. ${ }^{70}$

The human person is the heart of peace. ${ }^{71}$ Respect for the equal dignity of all human beings, we can say, is the deepest ethical foundation for building international relations that correspond to the authentic needs and hopes of all the peoples of the earth. 'Injustice, excessive economic or social inequalities, envy, distrust and pride raging among men and nations constantly threaten peace and cause wars. Everything done to overcome these disorders contributes to building up peace and avoiding war' (CCC 2317). Conflicts arise from forgetting this basic ethical foundation or partially and selectively accepting it. ${ }^{72}$ 'The culture of peace is built by rejecting at the outset every sort of racism and intolerance, by withstanding racist propaganda, by keeping economic and political ambition within due limits and by decisively rejecting violence and all forms of exploitation. ${ }^{73}$ Mutual respect will build trust and give rise to peace.

\section{Providing Humanitarian service}

Along with international secular institutions, non-governmental humanitarian organizations and religious bodies discreetly engage in peace negotiations without ulterior motives, promote peace between opposed groups and help to overcome ageold rivalries. They reconcile enemies, and open the way to a new and shared future. ${ }^{74}$ The Church is present in almost every nook and corner of the world with its own humanitarian services to help civilians caught in the line of fire. The International and national Caritas organizations and the Pontifical commission for Refugees are examples of such service.

\subsection{Preventing violence}

Armed conflicts and violence is a reality of our world. But we must be convinced that war is not inevitable. Political decisions precede most wars and mass violence. Peace builders should try their best to engage in peace building so as to prevent armed con-

\footnotetext{
${ }^{70}$ Benedict XVI, In Truth, Peace, No. 15.

${ }^{71}$ Idem, The Human Person the Heart of Peace, No. 1.

${ }^{72} \mathrm{D}$. Mamberti, Intervention by the Holy See at the $62^{\text {nd }}$ Session of the General Assembly of the Organization of the United Nations, New York, 1 October 2007, http://www.vatican.va/roman_curia/secretariat_state/2007/documents/rc_seg-st_20071001_mamberti-un_en.html (accessed November 23, 2013).

${ }^{73}$ John Paul II, Message..., No. 10.

${ }^{74}$ Idem, Peace on Earth..., Nos. 9-10.
} 
flicts. This preventive method is the essence of a culture of peace. ${ }^{75}$ Therefore, "negotiation between parties, with appropriate attempts at mediation and pacification by international and regional bodies, is of the greatest importance. ${ }^{976}$

\subsection{Education}

Attacks directly targeting humanitarian personnel are clear signs of disregard for humanitarian law. This calls on us to move beyond formulating and educating people about the juridical aspects of international humanitarian law. There is a great need to educate people on the great principles like the dignity of every human being, solidarity, primacy of law over force etc., that inspire humanitarian law. The Church engages in this education especially in the formation of Catholic military chaplains. ${ }^{77}$

\subsection{Education of the young}

Children, as noted at the beginning, are particularly disadvantaged in situations of armed conflict. Millions of children have been killed in recent conflicts around the world. They have also become direct targets of attacks. John Paul II rightly said: 'The deliberate killing of a child is one of the most disturbing signs of the breakdown of all respect for human life. ${ }^{78}$ Many have been maimed, systematically raped or killed in the name of ethnic cleansing. Many children and youth are not only victims, but they have been forced to take active part in armed conflicts. ${ }^{79}$ The Church, recognizing its responsibility, together with the entire world to 'give children a future of peace,' instructs Catholic institutions and organizations to give particular help to girls who have suffered as a result of war and violence and to teach boys to acknowledge and respect the dignity of women. ${ }^{80}$ There is also a commitment to children's education for peace which includes education in the family and in schools. ${ }^{81}$ Educational institutions have a 'duty to lead children gradually to understand the nature and demands of peace within their world and culture. Children need to learn the history of peace and not simply the history of victory and defeat in war. ${ }^{82}$

\footnotetext{
${ }^{75}$ R.R. Martino, Statement by H.E. Arch. Renato R. Martino Apostolic Nuncio, Permanent Observer of the Holy See before the First Committee of the General Assembly on Item 76 General and Complete Disarmament, New York, 14 October 1999, http://www.vatican.va/roman_curia/secretariat_state/documents/rc_seg-st_doc_14101999_disarmament_en.html (accessed November 23, 2013).

${ }^{76}$ John Paul II, Peace on Earth..., Nos. 9-10.

${ }^{77}$ S.M. Tomasi, Intervention by the Holy See at the $28^{\text {th }}$ International Conference of the Red Cross and the Red Crescent.

${ }^{78}$ John Paul II, Evangelium vitae Encyclical Letter (25 March 1995), AAS 87 (1995), n. 3.

${ }^{79}$ Idem, Let us give Children a Future of Peace, Message for the XXIX World Day of Peace, 1 January 1996, Nos. 2-3, http://www.vatican.va/holy_father/john_paul_ii/messages/peace/documents/hf_jp-ii_m es_08121995_xxix-world-day-for-peace_en.html (accessed November 23, 2013).

${ }^{80}$ John Paul II, Let us give Children a Future of Peace, Nos. 1, 4.

${ }^{81}$ Ibidem, No. 6.

${ }^{82}$ Ibidem, No. 9.
} 


\subsection{Overcoming fundamentalism and nihilism}

Terrorism is today one of the major challenges to peace. As pointed out by Benedict $\mathrm{XVI}$, both nihilism and fundamentalism can give rise to terrorism. Terrorism is often a sign of tragic and disturbing nihilism which has lost all hope in humanity, life and future. Everything becomes an object to be hated and destroyed. ${ }^{83}$ Pessimism in the face of suffering does not respect the victims. It lacks hope and critical realism which motivate victims to overcome their sufferings. ${ }^{84}$

Religious fanaticism or fundamentalism that imposes rather than proposes one's convictions about the truth on others is capable of giving rise to terrorist thinking and activity. ${ }^{85}$ To try to impose on others by violent means what we consider to be the truth is an offence against the dignity of the human being, and ultimately an offence against God in whose image he is made. ${ }^{86}$

Both nihilism and fundamentalism share 'an erroneous relationship to truth: the nihilist denies the very existence of truth, while the fundamentalist claims to be able to impose it by force. Despite their different origins and cultural backgrounds, both show a dangerous contempt for human beings and human life, and ultimately for God himself. ${ }^{97}$ As we discussed above, peace cannot be found without recognition of the truth of God and of man and hence, both nihilism and fundamentalism produce terrorism.

The Church believes that religion has the fundamental orientation to build peace. In the context of fundamentalism that gives rise to terrorism, the Church believes that it has the duty to demonstrate that religion is not and must not become a pretext for conflict and tries to declare without ambiguity that to promote violence or to wage war in the name of religion is a blatant contradiction. ${ }^{88}$ A clear example of the unambiguous teaching of the Church in this regard is the words John Paul II pronounced in the early phase of his pontificate and repeated throughout:

I join my voice today to the voice of Paul VI and my other predecessors, to the voice of your religious leaders, to the voices of all men and women of reason, and I proclaim, with the conviction of my faith in Christ and with an awareness of my mission, that violence is evil, that violence is unacceptable as a solution to problems, that violence is unworthy of man. Violence is a lie, for it goes against the truth of our faith, the truth of our humanity. Violence destroys what it claims to defend: the dignity, the life, the freedom of human beings. ${ }^{89}$

\footnotetext{
${ }^{83}$ Benedict XVI, In Truth, Peace, No. 9.

${ }^{84}$ M.L. Lamb, Solidarity with Victims: Toward a Theology of Social Transformation, The Crossroad Publishing, New York 1982, p. ix.

${ }^{85}$ Benedict XVI, In Truth, Peace, No. 9.

${ }^{86}$ John Paul II, No Peace without Justice No Justice without Forgiveness: Message for the World Day of Peace 2002, 1 January 2002, No. 6, http://www.vatican.va/holy_father/john_paul_ii/messages/peace /documents/hf_jp-ii_mes_20011211_xxxv-world-day-for-peace_en.html (accessed November 23, 2013).

${ }^{87}$ Benedict XVI, In Truth, Peace, No. 10.

${ }^{88} \mathrm{D}$. Mamberti, Intervention by the Holy See at the $62^{\text {nd }}$ Session of the General Assembly of the Organization of the United Nations.

89 John Paul II, Address at Drogheda, Ireland, September 29, 1979, No. 9, cited in: Pontifical Council for Justice and Peace, The International Arms Trade: An Ethical Reflection, 28 (italics added).
} 


\section{Conclusion}

However marred the world is by sin, hatred and violence, humanity's fundamental vocation is to be a single family. ${ }^{90}$ Being brothers and sisters is our identity and destiny and as Pope John XXIII in Pacem in Terries rightly said, no era will ever succeed in destroying the unity of the human family, for it consists of men who are all equal by virtue of their natural dignity, who feel in their consciences the natural imperative to work for the common good of all humanity. ${ }^{91}$

In the context of a discussion on 'Ethics in Economic Life,' the same principles discussed above with regard to situations of civilians caught in the line of fire could apply. Just as not every means is justified in legitimate defence, not every means is justified in economic efforts at improving human welfare. Human welfare cannot also be reduced to material wealth. Economic wellbeing is only one important aspect of human life. All aspects of our lives are connected to each other and we are linked to each other by our common origin. As we mentioned at the start of this article, decades of efforts to build wealth and remove poverty can be destroyed by a single war caused by unethical behaviour on the part of one community or another. True human welfare can be achieved only when ethical principles of universal brotherhood of all human beings, solidarity, common good, universal destination of goods, subsidiarity, human dignity and human rights are respected by each and every member involved. The common good of one cannot be in conflict with the common good of the other as individuals or as community.

Here, I would like to draw attention to a little incident in the life of Mahatma Gandhi. This incident clearly shows the importance of the means we choose to achieve the end. A reader of Gandhi's writings once objected to the teaching that ends and means are closely related like the seed and the tree - that ends do not justify the means. Gandhi responded to the reader with an example: 'If I want to deprive you of your watch, I shall certainly have to fight for it; if I want to buy your watch, I shall have to pay you for it; and if I want a gift I shall have to plead for it; and, according to the means I employ, the watch is stolen property, my own property, or a donation. Thus we see three different results from three different means. Will you still say that means do not matter?'92

Achieving appropriate goals utilizing only the morally right means is not a utopian proposal. 'Using nonviolent action, people have won higher wages, broken social barriers, changed government policies, frustrated invaders, paralyzed an empire and dissolved dictatorships. ${ }^{\prime 93}$ Not every means is justified in legitimate defence or in legitimate economic efforts. Ethics in economics should not be seen as a limit as often happens when one looks only from a mathematical perspective. Ethics is not an argument of losers but the stronghold of winners. Only ethical practices

\footnotetext{
${ }^{90}$ John Paul II, Peace on Earth..., No. 2.

${ }^{91}$ John XXIII, Pacem in Terris, No. 132.

${ }^{92}$ M.K. Gandhi, Hind Swaraj, or Indian Home Rule, pp. 110-126 [in:] On Violence, eds. B.B. Lawrence,

A. Karim, Duke University Press, Durham and London 2007, p. 118.

${ }^{93}$ G. Sharp, The Politics of Nonviolent Action. Part One: Power and Struggle, Porter Sargent Publishers, Boston 1973, p. ii.
} 
can truly improve the common good and make a true difference in increasing human welfare. In no situation should the economy pretend that ethics is not important, as not even in war is everything permissible or good.

\section{References}

African Union Convention for the Protection and Assistance of Internally Displaced Persons in Africa (2009), http://www.africa-union.org/root/AR/index/Convention\%20on\% 20IDPs\%20_Eng_\%20-\%20Final.pdf.

Benedict XVI, In Truth, Peace, Message of His Holiness Pope Benedict XVI for the Celebration of the World Day of Peace, January 1, 2006, No. 7, http://www.vatican.va/holy _father/benedict_xvi/messages/peace/documents/hf_ben-xvi_mes_20051213_xxxi $\mathrm{x}$-world-day-peace_en.html.

Benedict XVI, The Human Person the Heart of Peace: Message of His Holiness Pope Benedict XVI for the Celebration of the World Day of Peace, 1 January 2007, No. 14, http://www.vatican.va/holy_father/benedict_xvi/messages/peace/documents/hf_ben -xvi_mes_20061208_xl-world-day-peace_en.html.

Congregation for the Doctrine of the Faith, Donum Vitae On Respect for Human Life in Its Origin and on the Dignity of Procreation (February 22, 1987): AAS 80 (1988), Introduction.

Francis, War is a defeat for humankind, Pope Francis' homily during peace vigil, September 7, 2013, http://www.romereports.com/palio/pope-francis-homily-during-peace-vigi l-war-is-a-defeat-for-humankind-english-10953.html\#.UpDT4XmIodU.

Gandhi M.K., Hind Swaraj, or Indian Home Rule 110-126 [in:] On Violence, eds. B.B. Lawrence, A. Karim, Duke University Press, Durham and London 2007.

Holy See, Intervention by the Holy See at the Meeting of the Group of Governmental Experts, Geneva, July 15-26, 2002, http://www.vatican.va/roman_curia/secretariat_state/documents/rc_seg-st_doc_200 20723_martin-geneve_en.html.

John Paul II, Address at Drogheda, Ireland, September 29, 1979, No. 9, cited in: Pontifical Council for Justice and Peace, The International Arms Trade: An Ethical Reflection, 28.

John Paul II, Address to the members of the International Institute of Humanitarian Law, 18 May 1982, cited in: S.M. Tomasi, Intervention by the Holy See at the 28th International Conference of the Red Cross and the Red Crescent, Geneva, December 11, 2003, http://www.vatican.va/roman_curia/secretariat_state/2003/documents/rc_segst_20031209_red-cross_en.html.

John Paul II, Evangelium vitae Encyclical Letter, March 25, 1995, AAS 87 (1995), No. 3.

John Paul II, Let us give Children a Future of Peace, Message for the XXIX World Day of Peace, January 1, 1996, nos. 2-3, http://www.vatican.va/holy_father/john_paul_ii/me ssages/peace/documents/hf_jp-ii_mes_08121995_xxix-world-day-for-peace_en.html.

John Paul II, Message of His Holiness John Paul II on the Fiftieth Anniversary of the End of the Second World War in Europe, May 8, 1995, No. 7, http://www.vatican.va/holy _father/john_paul_ii/speeches/1995/may/documents/hf_jp-ii_mes_08051995_50thend-war-europe_en.html. 
John Paul II, No Peace without Justice No Justice without Forgiveness: Message for the World Day of Peace 2002, January 1, 2002, No. 6, http://www.vatican.va/holy_father/john_paul_ii/messages/peace/documents/hf_jp-ii_mes_20011211_xxxv-worldday-for-peace_en.html.

John Paul II, Peace on Earth to Those Whom God Loves, Message for the Celebration of the World Day of Peace, January 1, 2000, No. 3, http://www.vatican.va/holy_father/john _paul_ii/messages/peace/documents/hf_jp-ii_mes_08121999_xxxiii-world-day-forpeace_en.html.

John XXIII, Pacem in Terris Encyclical Letter (April 11, 1963): AAS 55 (1963), No. 10.

Lamb M.L., Solidarity with Victims: Toward a Theology of Social Transformation, The Crossroad Publishing, New York 1982.

Mamberti D., Intervention by the Holy See at the 62nd Session of the General Assembly of the Organization of the United Nations, New York, October 1, 2007, http://www.vatican.va/roman_curia/secretariat_state/2007/documents/rc_seg-st_20071001_mambe rti-un_en.html.

Martino R.R., Statement by H.E. Arch. Renato R. Martino Apostolic Nuncio, Permanent Observer of the Holy See before the First Committee of the General Assembly on Item 76 General and Complete Disarmament, New York, October 14, 1999, http:// www.vatican.va/roman_curia/secretariat_state/documents/rc_seg-st_doc_14101999 _disarmament_en.html.

Migliore C., Intervention by the Holy See at the Security Council of the United Nations on the Protection of Civilians in Armed Conflicts, New York, January 14, 2009, http://www.vatican.va/roman_curia/secretariat_state/2009/documents/rc_seg-st_20 090114_migliore-prot-civ_en.html.

Office for the Coordination of Humanitarian Affairs, Situation Report No. 26 as of 6 February 2015.

Paul VI, Address to the General Assembly of the United Nations, October 4,1965, AAS 57 (1965), No. 5.

Pius XI, Address to the Roman Curia, (December 24, 1930): AAS 22 (1930), pp. 535-536.

Pontifical Council for Justice and Peace, The International Arms Trade, An ethical reflection, Libreria Editrice Vaticana, Vatican City 1994.

Pontifical Council for Justice and Peace, The International Arms Trade: An ethical reflection, 12-13.

Sharp G., The Politics of Nonviolent Action. Part One: Power and Struggle, Porter Sargent Publishers, Boston 1973.

The Catechism of the Catholic Church: with Modifications from the Editio Typica, Doubleday, New York 1995.

Thomas Aquinas, Summa Theologiae.

Thomasi S.M., Statement by H.E. Archbishop Silvano M. Tomasi, Permanent Representative of the Holy See to the United Nations and Other International Organizations in Geneva at the Meeting of the High Contracting Parties to the Convention on Prohibitions or Restrictions on the Use of Certain Conventional Weapons which May Be Deemed to Be Excessively Injurious or to Have Indiscriminate Effects (CCW), Geneva, November 15, 2012, http://en.radiovaticana.va/storico/2012/11/15/statement _of_archbishop_tomasi_on_conventional_weapons_\%28full_text\%29/en1-639207. 
Tomasi S.M., Intervention by the Holy See at the $28^{\text {th }}$ International Conference of the Red Cross and the Red Crescent, Geneva, December 11, 2003, http://www.vatican.va/roman_curia/secretariat_state/2003/documents/rc_seg-st_20031209_red-cross_en.html.

Tomasi S.M., Intervention by the Holy See at the Humanitarian Affairs Segment of the UN Economic and Social Council, Geneva, July 20, 2009, http://www.vatican.va/roman_curia/secretariat_state/2009/documents/rc_seg-st_20090720_tomasi-aff-uman _en.html.

UN Secretary General's Report on the Protection of Civilians in Armed Conflict (S/1999/ 9578), September 1999, http://www.un.org/ga/search/view_doc.asp?symbol=S/19 99/957.

United Nations Assistance Mission in Afghanistan, Protection of Civilians in Armed Conflict - Afghanistan Mid-Year Report 2012, United Nations Assistance Mission in Afghanistan, Kabul 2012.

United Nations Assistance Mission in Afghanistan, Strategic Communications, February 18, 2015.

United Nations Security Council, Resolution 1296 (2000), preamble, http://www.undemocracy.com/S-RES1296(2000).pdf.

United Nations Security Council, Resolution 1894 (2009), preamble, http://www.unrol.org/ files/Security\%20Council\%20Resolution\%201894.pdf.

United Nations Security Council, Resolution 1960 (2010), Preamble, http://www.unwomen.org/ /me-dia/Headquarters/Attachments/Sections/News/In\%20Focus/16\% 20Days\%20of\%20Activism/UNSC_ Res-1960.pdf.

United Nations, The Universal Declaration of Human Rights, http://www.un. org/en/documents/udhr/.

United Nations, United Nations Millennium Declaration, adopted by the General Assembly on September 8, 2000, No. 26, http://www.un.org/millennium/declaration/ares552e.htm.

Vatican II, Gaudium et Spes Pastoral Constitution on the Church in the Modern World (December 7, 1965): AAS 58 (1966), No. 78. 